\title{
Digestion in the pre-ruminant animal
}

\author{
By J. W. G. Porter, National Institute for Research in Dairying, \\ Shinfield, Reading
}

The fore-stomachs of ruminant animals do not develop fully and assume their characteristic digestive functions until the young animal begins to eat substantial quantities of solid food. When young calves consume liquid feed nearly all of it by-passes the reticulo-rumen and passes through the omasum into the abomasum as a result of the reflex closure of the oesophageal groove. The subsequent course of events during digestion in the abomasum and small intestine has for long been regarded as being closely parallel to that in the stomach and intestines of monogastric animals. However, recent more detailed investigations of the processes of digestion have shown that the digestive capabilities and the development of digestive function in pre-ruminant animals differ in several respects from those in other young animals.

Efficient digestion and utilization of nutrients require that food pass at a suitable rate through an alimentary tract endowed with appropriate enzymes and absorptive mechanisms that will allow hydrolysis of complex molecules and absorption of the products. The passage into the lower gut of undigested or unabsorbed food residues provides a substrate for undesirable bacterial growth and may lead to diarrhoea. The digestive system of all young mammals is well adapted to the digestion of milk, and young pre-ruminant animals use the fat, protein and carbohydrate from milk with the same remarkable efficiency as do the young of other species. However, when nutrients are supplied from sources other than milk, it will be seen that certain digestive abilities of the pre-ruminant animal are found to be more limited, and either not to develop or to develop more slowly than those of other mammals.

\section{The course of digestion of liquid diets}

Whole milk. The sequence of events in the abomasum and small intestine of the milk-fed calf may be summarized from the results of the systematic studies with fistulated animals, carried out by Ash (1964), Smith (1964) and Mylrea (1966a,b). Before feeding, the abomasal contents consist of a fairly clear, slightly viscous fluid containing small milk clots and having a $\mathrm{pH}$ value of $\mathrm{I}-2$. During feeding, milk clots rapidly as it enters the abomasum and clotting is complete within a minute or so of finishing the meal. The $\mathrm{pH}$ value of the abomasal contents increases to around 6 immediately after feeding, but then, as the rate of acid secretion increases, the $\mathrm{pH}$ value decreases slowly and reaches pre-feeding values after about $5 \mathrm{~h}$. Feeding causes a considerable increase in the rate of outflow of abomasal contents and the rate of flow into the duodenum reaches a peak in the first hour after feeding, whereas in the jejunum the flow is greatest during the first $4-5 \mathrm{~h}$ after feeding; there is no marked effect of feeding on the pattern of flow in the ileum. The rate of emptying of the abomasum is approximately exponential, with about half the contents passing 
into the duodenum every $2 \mathrm{~h}$. As digestion in the abomasum proceeds the clot breaks up and the nature of the chyme passing into the duodenum changes $3^{-4} \mathrm{~h}$ after feeding from a whey-like fluid containing predominantly carbohydrate and soluble nitrogenous compounds, to a thick, white opaque material containing protein and fat. The $\mathrm{pH}$ values of duodenal contents reflect those in the abomasum, rising immediately after feeding to around 4 and falling thereafter. Feeding has little effect on $\mathrm{pH}$ values in the distal small intestine and there is a gradual increase towards the ileum where values are within the range $\mathrm{pH} 7-8$.

Owing to the continuous addition of saliva and abomasal secretions, the total volume of chyme leaving the abomasum is generally about twice the volume of milk fed, and there is some further addition of fluid to the chyme in the duodenum. The absorption of nutrients and water proceeds rapidly as the chyme passes down the small intestine. The volume of fluid entering the large intestine is only about onefifth of that of the milk fed.

Other diets. Changing the components of a complete diet has relatively little effect on the rate of abomasal emptying but may have a marked effect on the composition and rate of flow of digesta through the small intestine. Thus the rate of abomasal emptying, the pattern and volume of abomasal secretion and the $\mathrm{pH}$ values of the abomasal effluent were not consistently changed from those with whole cow's milk when the concentration of fat was altered (Ash, 1964) or when synthetic diets based on casein or soya-bean proteins were fed (R. H. Smith, private communication).

The transit time through the small intestine and volume of digesta reaching the ileum were similar with milk and with a synthetic diet containing casein. However, diets containing isolated soya protein passed markedly more rapidly through the intestine and yielded slightly greater volumes of digesta, and diets prepared from different samples of soya flour all showed a similarly increased rate of flow and a very marked increase in volume of digesta ( $R$. H. Smith, private communication). Little difference was found between the $\mathrm{pH}$ values of the contents of the small intestine in calves given milk or diets containing soya flour (Gorrill \& Thomas, I $967 b)$.

\section{Carbohydrates}

\section{Digestion and absorption of individual nutrients}

Whereas monosaccharides can be absorbed and passed into the blood stream intact, di- and poly-saccharides require hydrolysis to monosaccharides before effective utilization can take place. The enzymes responsible for hydrolysis in the gut are pancreatic amylase, which hydrolyses starch mainly to maltose, and the disaccharidases of the mucosal cells of the small intestine, which hydrolyse disaccharides to monosaccharides.

Carbohydrate utilization in the calf has been studied by measuring the response in the blood sugar concentration to carbohydrates given by mouth or infused directly into the duodenum, by determining intestinal carbohydrase activities, and in digestion trials. The results from the different approaches are generally in good agreement and it is well established that the young pre-ruminant calf readily 
utilizes glucose, galactose and lactose, but is unable to utilize sucrose, maltose and starch (Dollar \& Porter, I957, I959; Okamoto, Thomas \& Johnson, I959). Most studies of carbohydrate utilization by older calves have been made with ruminating animals (Velu, Kendall \& Gardner, 1960; Huber, Jacobson, McGilliard \& Allen, 196I), but similar findings with pre-ruminant calves of the effect of age have been reported recently by Siddons (1968a,b) and Siddons, Smith, Henschel, Hill \& Porter (1969).

Monosaccharides. Siddons et al. (1969) found that glucose, galactose and xylose were absorbed from the intestines of pre-ruminant calves of up to 106 days of age and each caused large increases in the concentration of blood reducing sugars. The responses to glucose and galactose were greater with $5^{0}$-day-old than with younger calves and at this age the maximum increase with glucose was greater than with galactose, though with younger calves the increases were similar. When glucose was given the whole of the increase was in blood glucose, but giving galactose caused only a small increase in blood glucose, and giving xylose was without effect on the glucose level. Preferential uptake of glucose occurred when a mixture of glucose and galactose was infused into the small intestine, though it is probable that both these sugars are actively absorbed. Fructose caused no increase in the level of reducing sugar in the blood of Io-day-old calves, but a small increase was found with $3^{\circ-}$ and $5^{0-d a y-o l d ~ a n i m a l s . ~ T h e ~ s e v e r e ~ s c o u r i n g ~ t h a t ~ o c c u r s ~ a f t e r ~ f e e d i n g ~}$ fructose indicates that much of the sugar passes unabsorbed through the intestine, though it is not yet established whether some absorption occurs, possibly accompanied by metabolic breakdown of fructose to lactic acid, as has been found with some other species.

$D i$ - and poly-saccharides. Lactose caused marked increases in the levels of both blood reducing sugar and blood glucose when fed to fasted calves and there was little difference in the response of calves of different ages up to 50 days. Maltose caused only small increases in blood sugar levels, though the response increased slightly with age. In the small intestine of the young calf lactase activity was high and maltase activity was low. In older calves lactase activity decreased though maltase activity did not increase.

Sucrose and starch caused no increase in the level of blood reducing sugar of preruminant calves. Sucrase activity could not be detected in the intestine and measured levels of pancreatic amylase were considerably lower than in monogastric animals. (Huber, Jacobson, Allen \& Hartman, 1961; Siddons, 1968a,b). The inference from these findings that sucrose and starch are not utilized is at variance with the results of digestion trials which indicate appreciable utilization of these sugars (Morrill, Jacobson, McGilliard \& Hotchkiss, I965; Huber, Natrajan \& Polan, I968). It seems probable that the disappearance of these sugars is the result of the action of micro-organisms in the lower gut, though small amounts of sucrose may be absorbed intact into the animal since $\left[{ }^{14} \mathrm{C}\right]$ sucrose was present in the urine of calves given this sugar (Xenoulis, Jacobson, Young, McGilliard \& Allen, 1967). 
Protein

Dietary proteins need to be hydrolysed to small peptides or amino acids before absorption. In most animals the necessary hydrolytic steps are carried out by pepsin, which is secreted in the stomach, by trypsin, chymotrypsin and carboxypeptidase, which are present in the pancreatic juice, and by various peptidases which are secreted into the small intestine or are present in the intestinal mucosal cells. There are no indications that pre-ruminant animals are deficient in proteolytic enzymes at any age, and additions to diets of proteolytic enzymes have not been found beneficial (Fries, Lassiter \& Huffman, I958).

Young calves, and possibly other young ruminants, differ from other young mammals in that they secrete two proteolytic enzymes, rennin and pepsin, in the abomasum or true stomach. The proportions of rennin and pepsin secreted vary markedly between calves. The exact pattern of secretion is not predictable from the age of the animal or the nature of its diet, and the total amount of proteolytic activity secreted does not change appreciably with age. Most calves show a transition from a secretion containing predominantly rennin during the first 2 weeks of life to one containing predominantly pepsin at 8 weeks of age, but a few calves secreted mainly pepsin from early life (Henschel, Hill \& Porter, 196r $a$; and unpublished results). It is uncertain whether the efficiency of protein utilization is in any way affected by the nature of the enzymes secreted, though little difference was found between results with pepsin and rennin for the in vitro digestion of raw milk (Henschel, Hill \& Porter, I96I $b$ ).

Studies of the proteolytic activity of the pancreas and pancreatic juice from pre-ruminant calves showed that seemingly adequate amounts of trypsin and chymotrypsin were produced from birth and that there was no marked increase in the concentration of enzymes with age (Gorrill \& Thomas, r965; Gorrill, Thomas, Stewart \& Morrill, 1967).

Milk proteins. The proteins of raw milk and of spray-dried milk are of high biological value and are generally well utilized by young calves. Casein serves as a reasonably satisfactory sole source of protein in synthetic diets for $\mathrm{I}-2$ week old calves and has given values for percentage nitrogen retention and apparent nitrogen digestibility of 35 and 86, compared with values for raw milk of 49 and 9I (Hill \& Porter, unpublished results). The proteins of milk that has been severely heattreated, as in the preparation of evaporated milk, are less well digested (Noller, Ward, McGilliard, Huffman \& Duncan, 1956). The more conservative heat treatments such as pasteurization, UHT processing and efficient spray- or roller-drying have little or no effect on the nutritive value of milk proteins for animals of most species. However it is well known that heating milk may cause denaturation of the whey proteins and from the series of papers by Roy and Shillam and their collaborators (cf. Roy, 1964) it is apparent that any heat treatment that results in the denaturation of more than about one-half of the whey proteins causes a reduction in the nutritive value of milk for young calves. Thus calves given UHT milk and spray-dried skim milk that had been submitted to a severe $\left(74^{\circ}\right.$ for $\left.30 \mathrm{~min}\right)$ preheating treatment grew significantly less well than calves given raw or pasteurized milk 
or spray-dried skim milk that had had a mild $\left(77^{\circ}\right.$ for $\left.\mathrm{r}_{3} \mathrm{sec}\right)$ preheating treatment.

Soya-bean proteins. The soya bean is one of the few vegetable materials that contains protein having a complete and reasonably well-balanced amino acid composition. Many unsuccessful attempts have been made to develop satisfactory diets for calves in which soya flour (finely ground, defatted soya-bean meal) provides the main or sole source of protein (Shoptaw, Espe \& Cannon, 1937; Stein, Knodt \& Ross, 1954; Iassiter, Fries, Huffman \& Duncan, 1959). Such diets often prove unpalatable to young calves and frequently cause severe diarrhoea.

Raw soya beans contain a heat-labile trypsin inhibitor and other factors causing a depression in food intake, poor growth, increased secretion of pancreatic enzymes and hypertrophy of the pancreas in young rats and chicks (Mickelson \& Yang, 1966; Sambeth, Neisheim \& Serajin, 1967). Soya-bean meal intended for animal feeds is usually heat-treated to destroy these toxic substances, but it is not known whether the materials used in the earlier trials with calves were suitably treated. The digestion of soya flour in the young calf was further studied by Gorrill \& Thomas $(1967 b)$ who found poor growth, but no hypertrophy of the pancreas, in calves given a methionine-supplemented diet in which soya flour containing trypsin inhibitor supplied $60 \%$ of the protein. The pancreatic juice and intestinal contents from the calves contained less trypsin and chymotrypsin activities than those from calves given milk or a soya flour having a very low content of trypsin inhibitor. The deleterious effects of the presence of trypsin inhibitor were confirmed by Colvin \& Ramsey ( 1968 ) though their major finding was that the nutritive value of trypsin inhibitor-free soya flour was markedly improved by treatment with acid at $\mathrm{pH}_{4}$ for $5 \mathrm{~h}$ at $37^{\circ}$. Calves given the acid-treated soya flour grew at nearly twice the rate of those receiving the untreated material. There is as yet no explanation of the nature of the alteration brought about by the acid treatment.

The isolated soya-bean proteins, ADM assay protein and $\alpha$-protein, offer an alternative though more expensive source of protein than soya flour. Trials with $I_{-2}$ week old calves given synthetic milk diets based on these proteins and supplemented with methionine have given values for percentage nitrogen retention and apparent nitrogen digestibility with ADM assay protein of $3 \circ$ and 75 and with $\alpha$-protein of $\mathrm{I}_{4}$ and $7_{2}$ (Hill $\&$ Porter, unpublished results).

\section{Fat}

The digestion of fat requires the presence of lipase which hydrolyses triglycerides to fatty acids and 2-monoglycerides before absorption can take place (cf. Garton, I969). Lipase is secreted in the pancreatic juice of the young calf; the levels of activity are high at birth and may double during the first weeks of life (Huber, Jacobson, Allen \& Hartman, I96r). A second lipase, pre-gastric esterase, released in the oral secretions of the pre-ruminant calf (Ramsey \& Young, I96I), appears to act in the abomasum in a manner similar to that of pancreatic lipase in the small intestine (Siewert $\&$ Otterby, I968) and, by cleaving butyric acid and smaller amounts of higher fatty acids from milk fat, causes the accumulation of free fatty acids in abomasal contents. The physiological significance of pre-gastric esterase in fat utilization is not known. 
Milk fat and other animal and vegetable fats emulsified to particle sizes of diameter less than $3-4 \mu \mathrm{m}$ are generally well digested and efficiently utilized by young calves, though a lower digestibility is found for fats rich in tristearin (cf. Raven \& Robinson, 1964). The depot fats of pre-ruminant animals, unlike those of adults, contain unsaturated fatty acids since these acids escape hydrogenation in the rumen (cf. Garton, 1967).

\section{Conclusions}

Although the foregoing discussion has been primarily concerned with processes of digestion and nutrient utilization in the young calf, it seems likely that broadly similar findings will be obtained with other young ruminants. Comparatively few such studies have so far been made, but the development of the secretion of carbohydrases in the young lamb was found to parallel that in the calf (Walker, 1959).

Further elucidation of the digestive capabilities of young pre-ruminant animals is a necessary preliminary to the formulation of satisfactory milk replacement diets. Present indications are that fat is generally well utilized by these animals but that the utilization of di- and poly-saccharides is restricted by deficiency of the appropriate hydrolytic enzymes, and the limited utilization of monosaccharides and certain proteins may reflect insufficiently developed systems for the absorption into the mucosal cells of the small intestine of simple sugars and the products of protein digestion.

\section{REFERENCES}

Ash, R. W. (1964). F. Physiol., Lond. 172, 425.

Colvin, B. M. \& Ramsey, H. A. (ro68). I. Dairy Sci. 51, 898.

Dollar, A. M. \& Porter, J. W. G. (1957). Nature, Lond. 179, 1299.

Dollar, A. M. \& Porter, J. W. G. (1959). Proc. int. Dairy Congr. xv. London. Vol. 1, p. 185.

Fries, G. F., Lassiter, C. A. \& Huffman, C. F. (1958). F. Dairy Sci. 4r, 108 r.

Garton, G. A. (1967). Wha Rev. Nutr. Diet. 7, 225 .

Garton, G. A. (1 g69). Proc. Nutr. Soc. 28, т3 .

Gorrill, A. D. L. \& Thomas, J. W. (1965). F. Anim. Sci. 24, 88z.

Gorrill, A. D. L. \& Thomas, J. W. (1967a). Analyt. Biochem. 19, 21 1.

Gorrill, A. D. L. \& Thomas, J. W. (1967b). Ұ. Nutr. 92, 215.

Gorrill, A. D. L., Thomas, J, W., Stewart, W. E. \& Morrill, J. L. (1967). F. Nutr. 92, 86.

Henschel, M. J., Hill, W. B. \& Porter, J. W. G. (ıg6ra). Proc. Nutr. Soc. 20, xl.

Henschel, M. J., Hill, W. B. \& Porter, J. W. G. (196rb). Proc. Nutr. Soc. 20, xli.

Huber, J. T., Jacobson, N. L., Allen, R. S. \& Hartman, P. A. (196I). F. Dairy Sci. 44, I 494.

Huber, J. 'T., Jacobson, N. I., McGilliard, A. D. \& Allen, R. S. (196r). F. Dairy Sci. 44, 321.

Huber, J. T., Natrajan, S. \& Polan, C. E. (1968). F. Dairy Sci. 5r, 108r.

Lassiter, C. A., Fries, G. F., Huffman, C. F. \& Duncan, C. W. (1959). Y. Dairy Sci. 42, 666.

Mickelson, O. \& Yang, M. G. (I 966). Fedn Proc. Fedn Am. Socs exp. Biol. 25, 104.

Morrill, J. L., Jacobson, N. L., McGilliard, A. D. \& Hotchkiss, D. K. (1965). F. Nutr. 85, 429.

Mylrea, P. J. (1966a). Res. vet. Sci. 7, 333 .

Mylrea, P. J. (1966b). Res. vet. Sci. 7, 394.

Noller, C. H., Ward, G. M., McGilliard, A. D., Huffman, C. F. \& Duncan, C. W. (1956). F. Dairy Sci. 39, 1288 .

Okamoto, M., Thomas, J. W. \& Johnson, T. L. (1959). F. Dairy Sci. 42, 920.

Ramsey, H. A. \& Young, J. W. (I961). F. Dairy Sci. 44, 2227.

Raven, A. M. \& Robinson, K. L. (1964). F. Sor. Dairy Technol. r7, 5.

Roy, J. H. B. (1964). Vet. Rec. 76, 5 I I.

Sambeth, W., Neisheim, M. C. \& Serajin, J. A. (1967). F. Nutr. 92, 479.

Shoptaw, L., Espe, D. L. \& Cannon, C. Y. (I937). F. Dairy Sci. 20, II7.

Siddons, R. C. (1968a). Proc. Nutr. Soc. 27, 18A. 
Siddons, R. C. (1968b). Biochem. F. 108, 839 .

Siddons, R. C., Smith, R. H., Henschel, M. J., Hill, W. B. \& Porter, J. W. G. (тg69). Br. F. Nutr. 23. (In the Press.)

Siewert, K. L. \& Otterby, D. E. (1968). F. Dairy Sci. 51, 1 305.

Smith, R. H. (1964). F. Physiol., Lond. r72, $3 \circ 5$.

Stein, J. F., Knodt, C. B. \& Ross, E. B. (1954). F. Dairy Sci. 37, 373.

Velu, J. G., Kendall, K. A. \& Gardner, K. E. (1960). F. Dairy Sci. 43, 546.

Walker, D. M. (1959). f. agric. Sci., Camb. 53, 374.

Xenoulis, P. K., Jacobson, N. L., Young, J. W., McGilliard, A. D. \& Allen, R. S. (1967). F. Anim. Sci. 26, 933 .

\title{
Post-abomasal digestion of carbohydrate in the adult ruminant
}

\author{
By D. G. Armstrong and D. E. Beever, \\ Department of Agricultural Biochemistry, University of Newcastle upon Tyne
}

Gray ( 1947 ) studied sites of digestion in sheep of the cellulose contained in a mixed ration of lucerne hay and wheat straw by applying the lignin ratio technique to analyses of digesta obtained from slaughtered animals. The technique has also been used by Hale, Duncan \& Huffman (1947) to study cellulose digestion in cows fed lucerne hay, by Marshall (I949) to study the digestion of pentosans in sheep fed hay and by Rogerson (1958) to study digestion of crude fibre and nitrogen-free extractives contained in three rations fed to sheep. Apart from errors that may arise from the use of lignin as an indigestible marker, results obtained using the above method suffer the disadvantage that they relate to conditions pertaining in the tract at specific times after feeding. The development of techniques for inserting re-entrant cannulas into various parts of the alimentary tract of the ruminant has greatly facilitated studies in this field (Phillipson, 1952; Ash, 1962).

\section{Extent and sites of digestion of starch}

Table I shows the extent and sites of digestion of starch in rations fed to both sheep and cattle, and Table 2 gives additional information for starch contained in diets fed to sheep only. 'The results presented in Table I show that for the feeds examined there is good agreement between sheep and cattle regarding overall digestibility of starch and, in four of the six feeds examined, the extent to which it is digested in the reticulo-rumen. In the case of the rations containing 20 and $80 \%$ ground maize the results suggest that more starch enters the small intestine in cattle than in sheep. The results in Table I do not allow a comparison to be made between sheep and cattle on the extent to which starch entering the small intestine is digested therein or is lost in subsequent passage through the caecum and colon. The slightly lower values shown in Table I for digestibilities of starch for sheep (Tucker, Mitchell \& Little, I968) compared to cattle, when rations containing $20-60 \%$ ground maize were fed, are of doubtful significance. Each coefficient is the mean of 